\title{
Jigsaw and Dictogloss Tasks: Do They Facilitate the Development of Speech Acts?
}

\section{Mojgan Rashtchi ${ }^{1 *}$, Reza Porkar $^{1}$, \& Seyyede Fateme Ghazi MirSaeed ${ }^{1}$}

* Correspondence:

m_rashtchi@iau-tnb.ac.ir

1. TEFL Department, Faculty of

Foreign Languages, North Tehran

Branch, Islamic Azad University

Received: 27 July 2019

Revision: 7 October 2019

Accepted: 12 November 2019

Published online: 20 March 2020

\section{Abstract}

Speech acts have a decisive role in enabling EFL learners to communicate successfully. This study compared the efficacy of jigsaw and dictogloss tasks in learning speech act by 47 pre-intermediate adolescent EFL learners. The participants were selected based on convenience sampling and were homogenized based on the results of a PET. Discourse- completion task (DCT) was employed as the pre and post-tests. The result of the DCT pretest showed that the participants were not familiar with the target speech acts. Twenty 3-minute vignettes taken from different films were employed as the medium of instruction. After the treatment, the participants sat for another DCT. The results revealed that there was no statistically significant difference between the groups regarding knowledge of speech acts. However, the results of the paired samples t-test conducted to ensure the effectiveness of the treatment showed that there was a statistically significant difference between the groups' DCT pre and post-tests. The study revealed that task type did not have a crucial role in learning speech acts; however, it encouraged the use of films for teaching speech acts.

Keywords: dictogloss tasks, jigsaw tasks, film-based instruction, pragmatic competence, speech acts 


\section{Introduction}

Pragmatic competence, which refers to the use of language in a context necessitates appropriate use of language and requires adequate linguistic and pragmatic knowledge as well as the ability to employ the knowledge in interaction (Taguchi, 2006). Pragmatics, as Bach (2006) argues, involves speech acts, communicational information, and meanings that a speaker aims to convey beyond the meaning of words. Speech acts as a vital component of pragmatics refer to the understanding of the actions which individuals perform while speaking, which is automatic for native speakers (Holtgraves, 2007). However, for non-natives, teaching speech acts, without which "communication of intentions would be impossible" (Ambroise, 2010) seems necessary.

Communication is built on the successful interaction of the interlocutors and requires cultural knowledge and understanding (Arundale, 2004). It is evident that the more significant are the differences in the interlocutors' cultural skills and knowledge, the more pragmatic failure is likely to occur. Norms vary in different cultures, and thus for proper communication, second language learners need knowledge of pragmatics, besides linguistic knowledge (Rose \& Kasper, 2001). Two distinct aspects of pragmatic competence, namely pragmalinguistics and sociopragmatics, may facilitate communication. Pragmalinguistic failure may occur when the pragmatic force of a linguistic structure differs from that of a typical native speaker and is the primary reason for the occurrence of errors, which arise from inappropriate use of speech act strategies. Sociopragmatic failure, however, originates from the diverse intercultural perceptions of appropriate linguistic behavior. Therefore, language learning without learning "culturally appropriate language usage and discourse" (Milleret, 2006, p.31) cannot lead to communication.

\subsection{Statement of the Problem}

In EFL contexts, learners do not have the advantage of exposure to the language which naturally occurs in the environment, and that is why the process of learning becomes a cumbersome task. One solution is to teach speech acts that exist in interpersonal discourse (Yi-xuan, 2016) to facilitate communication and assist learners to build social lives (Arundale, 2004). Speech acts, as Milleret (2006) puts forward, enable learners to understand "non-verbal expressions" within a cultural context, and failure in such communication can result in "embarrassment, laughter, misunderstandings, or even outrage" (p.30).

Therefore, to facilitate cultural understanding and communication, this study employed a series of films to teach speech acts to English as a Foreign Language (EFL) learners. To obtain the purpose of the study, two types of tasks, that is, jigsaw and dictogloss tasks were used. The reason for implementing the two task types was that jigsaw is an interactive-focused task that invests in the interaction among learners, while dictogloss is a written production focused task which tries to draw learners' attention to a specific feature. The researchers of the current study assumed that implementing the two types of tasks could facilitate the process of learning the speech acts and thus could contribute to the development of cultural understanding and could increase learners' awareness of different types of speech acts. Also, it was presumed that teaching the speech acts would allow Iranian EFL learners to interact in the language with more ease and would help them materialize the linguistic knowledge they possessed due to studying the grammar and vocabulary of English previously. It is worth mentioning that dictogloss and jigsaw tasks have been implemented in different studies and for investigating various components of language (e.g., Jafariyan Shahri, Matlabi, Esmaeili, \& Kianmehr, 2017; Marashi \& Khaksar, 2013; Meng, 2010; Rashtchi \& Khosroabadi, 2009; Yulian, 2012).

However, the comparative effect of such tasks on teaching the speech acts has not been addressed previously. Moreover, teaching speech acts have been investigated by different researchers in different contexts (e.g., Ebadi \& Seidi, 2015; Konakahara, 2011; Martinez-Flor \& Fukuya, 2005); however, to the best of the researchers' knowledge, no studies have compared the impact of jigsaw and dictogloss tasks on teaching the speech acts. Therefore, the two task types were employed to address the main issue of the study which was lack of sufficient communicative skills which can be achieved via familiarity with the speech acts as components of pragmatic competence.

\subsection{Research Question}

The researchers of the present study formulated the following research question to explore the problem under investigation and achieve the primary aim of the study:

RQ: Is there any difference between the effects of dictogloss and jigsaw tasks on improving adolescent EFL learners' knowledge of speech acts? 


\subsection{Null Hypothesis}

The following null hypothesis was formulated to enable the researchers to answer the research question of the study:

H0: There is no statistically significant difference between the speech act knowledge of the dictogloss task group and the jigsaw task group.

\section{Review of the Literature}

Input plays a crucial role in the acquisition of communicative competence, including pragmatic competence. However, Kasper and Roever (2005) argue that mere exposure to input is not adequate to trigger pragmatic development in a new language due to the complexity of pragmatic competence. Many studies have addressed the role of input in improving speech acts as a component of pragmatic competence. For example, Winke and Teng (2010) have studied the effect of teaching compliments to Chinese learners of English and have shown the crucial role of explicit instruction of speech acts. Refusals, another category of speech acts, have been the subject of a study by Kondo (2008), who showed that Japanese learners could benefit from explicit instruction. Also, Takahashi (2001) found that from different treatments used, the group receiving explicit instruction could outperform the other three groups of the study. In the same line, Ishihara $(2004,2007)$ reported the usefulness of the explicit instruction of speech acts in the successful communication of Japanese students. Likewise, several scholars believe that formal instruction can provide the required input for learning speech acts (Nguyen et al., 2012; van Compernolle \& Williams, 2013).

The importance of input in the acquisition of speech acts, as Lee (2018) puts forward, draws attention to Swain's (2005) output hypothesis, Schmidt's noticing hypothesis (2001), and Long's input and interaction hypothesis (1996). Swain's output hypothesis, which involves learners' active production of language in the process of L2 acquisition, introduces three functions for output; that is, the noticing/triggering function, the hypothesis testing function, and the metalinguistic (reflective) function. These functions inform learners of the development of their language systems in a way that they can process it not only at a semantic level but also at a syntactic one. However, mere exposure to L2 input cannot do this for the learners, and output plays a parallel role between second language acquisition and second language competence, respectively, in terms of morphosyntactic development and learners' developing L2 pragmatics.

The capability of applying pragmatics and Schmidt's noticing hypothesis has been studied extensively; however, from a cognitive perspective, Bialystok's (1993) model and Long's (1996) interaction hypothesis have also stimulated interlanguage pragmatics research. For example, the study by Hassall (2003) confirms Bialystok's suggestions that when L2 learners choose to develop pragmatic knowledge, their reflection on pragmatic representations leads to the dominance of such representations in their attention. Additionally, Kasper (2001) insists on the need to distinguish the language in use from the metalinguistic knowledge as well as pragmatics and metapragmatics while he tries to make focus on form versus focus on forms in pragmatics practicable within the framework of Long's (1996) interactive hypothesis which assigns a facilitative role to interaction in the process of the second language acquisition since it can enable language learners to produce more accurate utterances. The overall emphasis of the interaction hypothesis is that incidental language learning is simplified in an oral interaction where there is a communication breakdown and, consequently, a negotiation over the problem (Rashtchi \& Keyvanfar, 2007).

Various studies indicated that pragmatic competence could develop through incidental communication in daily life interactions. These studies blur the effectiveness of explicit teaching of the pragmatic components. For example, Taguchi (2008) verified the role of language proficiency in successful comprehension of pragmatic features by Japanese learners of English. Also, Shively's (2011) longitudinal study showed the development of pragmatic choices of the English-speaking participants during interaction with Spanish native speakers. In comparing EFL and English as a Second Language (ESL) German participants who were learning English, Schauer (2006) concluded that ESL learners had a significantly higher level of pragmatic awareness due to natural exposure to the English language. In opposition to the studies mentioned so far, are the results found by Martinez-Flor and Fukuya (2005), who reported that explicit and implicit instructions were effective in improving participants' production of pragmatically appropriate head acts and down graders in suggestions. Their study, however, signifies the role of input in promoting pragmatic competence.

\subsection{Jigsaw and Dictogloss Tasks}

Jigsaw tasks are interactive tasks that create multiple roles for learners as they negotiate to complete them (Sykes, 2008). In Jigsaw tasks, according to Ellis (2003), the input material is divided between the learners so that they have 
to interact and support each other to accomplish them. They are two-way information-gap tasks that include many confirmation checks, comprehension checks, and clarification requests and recasts. While completing jigsaw tasks, language learners notice their comprehension problems and try to solve them through communication with peers (Lestik \& Plous, 2012).

On the other hand, dictogloss, as output-based focus on form technique, is believed to improve language at discourse level as it focuses on the meaning of a whole text (Jacobs \& Small, 2003; Qin, 2008). Dictogloss tasks in their fourstep procedure of preparation, dictation, reconstruction, and analysis with correction (Wajnryb, 1990) provide L2 learners with a meaningful context while enabling them to focus on grammatical structures of the target language to reproduce a text. Dictogloss tasks cultivate interaction and negotiation and thus transform classrooms into a cooperative learning environment. They can draw the learners' attention to meaning, foster focus on form, and cultivate interaction among peers, the characteristics that conform to Ellis' (2005) set of general principles for language pedagogy.

The use of jigsaw tasks in second language teaching has been investigated from different perspectives. Some scholars have addressed their efficacy on the reading skill (e.g., Meng, 2010; Yulian, 2012), the writing skill (e.g., Sitohang \& Purnawarman, 2015; Zahra, 2014). Kilic (2008) studied the role of the jigsaw on learning the concepts of the principles and methods of teaching and concluded that it had enhanced the learning of the participants. Jafariyan Shahri et al. (2017) reported that jigsaw could improve medical students' scores on physics more than lectures.

Likewise, several studies have employed dictogloss to teach different aspects of language. For example, dictogloss has been shown to be useful in teaching grammar (Nguyen, 2017; Qin, 2008; Rashtchi \& Khosroabadi, 2008), in promoting the writing ability of English language learners (e.g., Bataineh \& Bani Younis, 2016; Murad, 2017), dictation (e.g., Faghani, Derakhshan, \& Zangoei, 2015), and listening comprehension (e.g., Marashi \& Khaksar, 2013; Vasiljevic, 2010).

Jigsaw and dictogloss tasks have also been compared in the domain of L1 use in language learning classes. For example, Zeng (2017) examined the two task types in face-to-face and synchronous computer-mediated communication modalities and found that dictogloss was more effective in enhancing language-related episodes. Also, Swain and Lapkin's (2000) study explored the use of jigsaw and dictogloss tasks in two classes to study L1 interactions and found that task type did not affect the amount of L1 use. Yilmaz (2011) compared the use of dictogloss and jigsaw tasks and found that dictogloss has been more effective in eliciting language-related episodes in synchronous computer-mediated communication.

\subsection{Pragmatic Development}

Speech acts, as Searle (1976) defines, include communicative actions in forms of spoken or written language in the social and cultural context, which express the message or the intended impression of a speaker. Bara (2010) clarifies that the separate analysis of speech acts ignores how speech acts are seated within dynamic conversational contexts. Moreover, textbooks are incapable of equipping learners to utilize speech acts successfully (Khemlani David, 2016; Latif, 2014). One way to teach speech acts is to use films and videos which provide the context in which speech acts occur. They provide productive contextual factors and enable learners to experience how speech acts are used in reallife like communications. The authentic use of speech acts by the characters of the films can introduce the cultural values that learners should follow while engaged in communication. The advantage of employing films as the medium which can activate learners' attention toward speech acts has been emphasized in the literature (e.g., Abrams, 2014; Borer, 2018; Ishihara, 2014). Likewise, in their study, Birjandi and Derakhsahn (2013), who employed video-driven prompts to examine the comprehension of speech acts, believe in their facilitative role for teaching speech acts. Also, Khemlani David (2016) showed the efficacy of employing movies for the teaching of speech acts of refusals. In another study, Grant and Stark (2001) showed the primacy of soap opera materials to textbooks in teaching conversational closings.

Moreover, films and media have been used in several studies to examine their effectiveness in teaching cultural values of English. For instance, Reece and Palmgreen (2000) investigated Indian immigrants of the United States and concluded that media had a crucial role in filling the cultural gaps of the immigrants. Likewise, Moon and Park (2007) considered media as the most substantiate variable that forwards the process of cultural familiarization. Therefore, it can be concluded that authentic audio-visual materials can offer a more fruitful source of input for language learners and can be used in different ways and on various levels to enhance learners' communicative competence (Gilmore, 
2007). In the same vein, the present study employed authentic movies as extra-curricular instruments that reduce students' tension and positively affect the process of acculturation and adaptation to a new culture. The researchers of the present study believed that movies could enhance learners' motivation for learning pragmatics and could promote their ability to efficiently using speech acts.

\section{Methodology}

\subsection{Design of the Study}

This study was a quasi-experimental one as the random selection of the participants was not feasible. From among different quasi-experimental designs, the non-equivalent control group pretest-posttest design was implemented to examine the impact of the jigsaw and dictogloss tasks on the learning of speech acts by Iranian EFL learners. The dependent variable was learning the speech acts, and two teaching modes; that is, jigsaw and dictogloss tasks, were used as independent variables to manipulate the treatment. Two groups in two intact classes were selected to receive the treatment modes and help researchers to achieve the objectives of the study.

\subsection{Participants}

Initially, 50 junior high school students from a girls' state-school in Tehran in two intact classes $(n 1=n 2=25)$ took a Preliminary English Test (PET). They were taking extracurricular English courses (i.e., other than English courses devised by Iran's Ministry of Education in the official curriculum) provided by the school administrators and had paid the tuition fee for attending the classes. The result of the PET signified that the scores of three students were beyond one standard deviation below the mean (51 and 53) and above the mean (96). Therefore, they were placed in other English classes in the school and were excluded from the present study. The 47 participants, who were selected based on convenience sampling, were between the age range of 14 and 16 years old and were from the same L1 backgrounds. The two homogeneous classes were assigned randomly to the jigsaw group $(n=22)$ and the dictogloss group $(n=25)$ after taking the PET.

\subsection{Instruments}

The first instrument, as mentioned above, was the PET employed to examine the homogeneity of the participants. The paper-based PET is a B1 or low intermediate test that consists of reading and writing (90 minutes), listening (30 minutes), and speaking (a 10-minute interview). There are 35 reading questions, each of which scores one mark. The writing section consists of three parts: 1) sentence transformations, 2) writing a short message, and 3) writing an informal letter, or a story. Writing parts are marked out of 6, 5, and 15, respectively. The listening section has 25 questions, and each scores one point. The speaking section is performed with two participants and two examiners. One of the examiners talks to the participants; however, the other does not participate in the conversations. The Speaking section includes three parts, and it is worth $25 \%$ of the total score for the exam. The examiners were two teachers from the same school who volunteered to perform the speaking test.

Two Discourse-Completion Tasks (DCTs) were used as the pre-test and post-test (Appendix A \& Appendix B). DCT describes a situational prompt, and the participants are asked to answer the relevant questions. According to Boxer (2002), there are two types of DCT; one in the form of an open-ended questionnaire in which the learners are required to provide an accurate speech act corresponding to the defined prompt. Another is in the form of a closed questionnaire that elicits a specific speech act from the participant, followed with a blank line and then a response that is given by the first speaker, respectively. In the current study, the researchers employed a modified version of the open-ended DCT, which consisted of 20 items asking about the speech acts that were the focus of the present study.

\subsection{Instructional Materials}

The groups were exposed to English native speaker interactions through 20 movie vignettes. Speech acts in question belonged to two categories of expressive and directives. Expressive speech acts required the participants to produce surface forms representing deep motives while the directives needed the socially acceptable use of politeness techniques. The speech acts consisted of request refusals, compliment responses, advice-giving, and invitations. Overall, five vignettes for each speech act and a total number of 20 scenarios were employed. The movies used in the treatment were Horse Whisperer (Redford, 1998; to teach request refusals and advice-giving), Half Nelson (Fleck, 2006; to show request refusal and compliment responses), The Descendants (Payne, 2011; to show invitations and advice-giving), and World's Greatest Dad (Goldthwait, 2009; to show complement responses and invitations). 


\subsection{Data Collection}

The study took 12 sessions for six weeks. Two sessions were devoted to administering the PET (one session for the speaking section and one for other parts). Then the participants sat for DCT as the pre-test to ensure that they were not familiar with the speech acts that were going to be taught during the treatment. Afterward, the two intact classes were randomly assigned to the jigsaw group $(n=22)$ to go through an interactive-focused instruction and dictogloss group $(n=25)$ to follow output-based tasks instruction. Each session, two 3-minute video vignettes corresponding to a specific speech act were played in both groups.

\subsubsection{Jigsaw Group}

The researchers adopted Mengduo and Xiaoling's (2010) classroom procedure in the jigsaw group. The teacher divided the class into groups of three or four and played a three-minute video vignette two times to the class. For the first time, the students were expected to watch the film and take notes if needed. The second time, after playing the film, the teacher described the context of the prompt. During the description, the teacher defined and wrote unfamiliar words and expressions on the board to facilitate the flow of activities of the day. Then the teacher gave the film scripts to the students and asked them to read them. The purpose of providing the scripts was to expose the learners to both structure and content. In the next step, the teacher asked some WH-questions to attract the students' attention to the use of the speech acts. Afterward, the students handed over the scripts and were ready for the jigsaw task. The conversations in the vignettes were split into three or four parts, and each part (depending on the number of the groups) was printed on a separate piece of paper and given to each member of a jigsaw group so that the students in each group had the same part of the vignette. Then each student with a piece of paper left the jigsaw group to find other students who had different parts of the scenario. Thus, they had to form a new group. They discussed the complete version of the script with other members of the new group to learn it, while one member had been chosen by the teacher to be the leader. Finally, each student retold the contents to the group.

When all participants learned the complete version of the script, they formed their initial groups and shared their material and knowledge with other members. Each student read aloud her part for the group. As the final step, the participants engaged in role-playing in front of the class. The class selected the best performance, and the teacher gave an extra credit that was added to their final score, later. When necessary, the teacher gave feedback on the role-plays.

During the task, the teacher merely observed the students and intervened when students asked. After the task, the teacher tried to draw the students' attention toward the prompt and the related speech act and explain its sociolinguistic characteristics such as power, social distance, and the size of imposition.

\subsubsection{Dictogloss Group}

The classroom procedure in this class consisted of five steps. First, the teacher paired the students and played the video vignette. Next, the vignette scripts with the bold-faced speech acts were distributed among the pairs to enhance their focus on the target structures. Similar to the jigsaw group, the film was played twice. During watching the movie for the second time, the participants could read the scripts and take notes. Third, the teacher collected the scripts and asked the pairs of students to work together and write as much as they could remember from the scenario. In the following step, one member of each pair read their composition to the class while other students were listening carefully and commenting on the missing parts. The class judged which script should receive the extra credit of the day. In the last step, when all the pairs of the students had read their summaries, the teacher wrote the target speech acts on the board to draw the students' attention to their correct form. Then, similar to the jigsaw group, the teacher explained the sociolinguistic characteristics of the speech act, including power, social distance, and the size of imposition governing the choice of the speech act for each situation. During the readings, the teacher intervened, corrected the grammatical and pragmatic errors, made comments, and wrote some points on the board when necessary.

\subsection{Data Analysis}

To come up with reasonable conclusions, the researchers ran independent samples t-test and paired samples t-test. Descriptive statistics were also used to highlight the characteristics of the sample.

\section{Results}

As mentioned above, the researchers administered the PET to 50 junior-high-school students at the onset of the study and excluded three students whose scores fall beyond one standard deviation above and below the mean. Table 1 
shows the descriptive statistics of all students on the PET. As the results show, the lowest score was 51, and the highest score was 96, and the standard deviation was 6.7. The result of skewness (obtained from dividing the statistic by the standard error) was -6.63 and far beyond \pm 1.96 . Therefore, as it could be inferred, the distribution of the scores was not normal, and the outliers had to be excluded from the study.

Table 1. Descriptive statistics of the PET before excluding the outliers

\begin{tabular}{|c|c|c|c|c|c|c|c|}
\hline \multirow{2}{*}{\multicolumn{2}{|c|}{$\begin{array}{c}\mathrm{N} \\
\text { Statistic }\end{array}$}} & \multirow{2}{*}{$\begin{array}{l}\text { Minimum } \\
\text { Statistic }\end{array}$} & \multirow{2}{*}{$\begin{array}{c}\text { Maximum } \\
\text { Statistic }\end{array}$} & \multirow{2}{*}{$\begin{array}{c}\text { Mean } \\
\text { Statistic }\end{array}$} & \multirow{2}{*}{$\begin{array}{c}\text { Std. Deviation } \\
\text { Statistic }\end{array}$} & \multicolumn{2}{|c|}{ Skewness } \\
\hline & & & & & & Statistic & Std. Error \\
\hline Groups & 50 & 51 & 96 & 78.78 & 6.77718 & -2.237 & .337 \\
\hline
\end{tabular}

Table 2 shows the descriptive statistics of the sample, after discarding the scores of the outliers. As shown in the table, the minimum score is 70 , and the maximum score is 86 , with a standard deviation of 3.2. Comparing this standard deviation from the one obtained from Table 1 shows that the dispersion among the scores decreased after excluding the scores which did not cluster around the mean. The skewness ratio equal to -0.85 (between \pm 1.96 ) enabled the researchers to conclude that the distribution of the scores enjoyed the normality criterion at the outset of the study.

Table 2. Descriptive statistics of the PET after excluding the outliers

\begin{tabular}{|c|c|c|c|c|c|c|c|}
\hline \multirow{2}{*}{\multicolumn{2}{|c|}{$\begin{array}{c}\mathrm{N} \\
\text { Statistic }\end{array}$}} & \multicolumn{2}{|c|}{ MinimumMaximum } & \multirow{2}{*}{$\begin{array}{c}\text { Mean } \\
\text { Statistic }\end{array}$} & \multirow{2}{*}{$\begin{array}{c}\text { Std. Deviation } \\
\text { Statistic }\end{array}$} & \multicolumn{2}{|c|}{ Skewness } \\
\hline & & Statistic & Statistic & & & Statistic & Std. Error \\
\hline$\overline{\text { Group }}$ & 47 & 70 & 86 & 79.5532 & 3.26243 & -.296 & .347 \\
\hline
\end{tabular}

To provide a clearer picture of the participants' language proficiency scores, the researchers calculated the descriptive statistics for each group separately. Table 3 shows the results. The means of Group $1(\mathrm{M}=79, \mathrm{SD}=3.5)$ and Group 2 $(\mathrm{M}=80, \mathrm{SD}=3.01)$ were close, and the ratio of skewness for Group 1 is -0.72 , and for Group 2 is -0.17 , both falling between \pm 1.96 that signify the normality of the distribution.

Table 3. Descriptive statistics of the PET for each group

\begin{tabular}{cccccccc}
\hline & $\mathrm{N}$ & $\begin{array}{c}\text { Minimum } \\
\text { Statistic }\end{array}$ & Statistic & Statistic & Statistic & Statistic & Std. Error \\
\hline Group 1 & 22 & 70.00 & 86.00 & 79.0455 & 3.52511 & -.357 & .491 \\
Group 2 & 25 & 74.00 & 86.00 & 80.0000 & 3.01386 & -.079 & .464 \\
\hline
\end{tabular}

Table 4 shows the results of the independent samples t-test run between the means of the groups. The Levene's test revealed that the two groups were homogenous in terms of their variances $(F=0.002, p=0.96)$. The result of the independent samples t-test between Group $1(\mathrm{M}=79.04, \mathrm{SD}=3.52)$ and Group $2(\mathrm{M}=80, \mathrm{SD}=3.01)$ showed no statistically significant difference; $\mathrm{t}(47)=-1.0, \mathrm{p}=0.32$ ). 
Table 4. Independent samples t-test on PET

\begin{tabular}{|c|c|c|c|c|c|c|c|c|c|}
\hline & \multicolumn{2}{|c|}{$\begin{array}{c}\text { Levene's Test for } \\
\text { Equality of } \\
\text { Variances }\end{array}$} & \multicolumn{7}{|c|}{ t-Test for Equality of Means } \\
\hline & \multirow[t]{2}{*}{$\mathrm{F}$} & \multirow[t]{2}{*}{ Sig. } & \multirow[t]{2}{*}{$\mathrm{T}$} & \multirow[t]{2}{*}{$\mathrm{df}$} & \multirow[t]{2}{*}{$\begin{array}{c}\text { Sig. } \\
\text { (2-tailed) }\end{array}$} & \multirow[t]{2}{*}{ Mean Dif. } & \multirow[t]{2}{*}{$\begin{array}{l}\text { Std. Error } \\
\text { Dif. }\end{array}$} & \multicolumn{2}{|c|}{$\begin{array}{l}\text { 95\% Confidence } \\
\text { Interval of the Dif. }\end{array}$} \\
\hline & & & & & & & & Lower & Upper \\
\hline $\begin{array}{c}\text { Equal } \\
\text { Variances } \\
\text { Assumed }\end{array}$ & .002 & .962 & -1.001 & 45 & .322 & -.95455 & .95369 & -2.87538 & .96629 \\
\hline
\end{tabular}

The results of the descriptive statistics of the DCT pretest are illustrated in Table 5. The means of the jigsaw group $(\mathrm{M}=8.36, \mathrm{SD}=1.04)$ and the dictogloss group $(\mathrm{M}=8.24, \mathrm{SD}=.92)$ are shown to be very close. Also, as the standard deviations show, the participants' scores are clustered around the mean.

Table 5. Descriptive statistics on DCT pre-test

\begin{tabular}{cccccc}
\hline & & & Std. & Std. Error Mean \\
& & $\mathrm{N}$ & Mean & Deviation & .22356 \\
\hline Groups & Jigsaw Group & 22 & 8.3636 & 1.04860 & .18511 \\
& $\begin{array}{c}\text { Dictogloss } \\
\text { Group }\end{array}$ & 25 & 8.2400 & .92556 & \\
\hline
\end{tabular}

Additionally, the Leven's test (Table 6) signifies that the variances of the groups were homogeneous $(\mathrm{F}=.60, \mathrm{p}=0.43)$. The result of the independent samples t-test between jigsaw group $(\mathrm{M}=8.36, \mathrm{SD}=1.04)$ ) and dictogloss group ( $\mathrm{M=8.24}$, $\mathrm{SD}=.92$ ) showed no statistically significant difference between the groups; $\mathrm{t}(45)=0.42, \mathrm{p}=0.67)$.

Table 6. Independent samples test on DCT pre-test

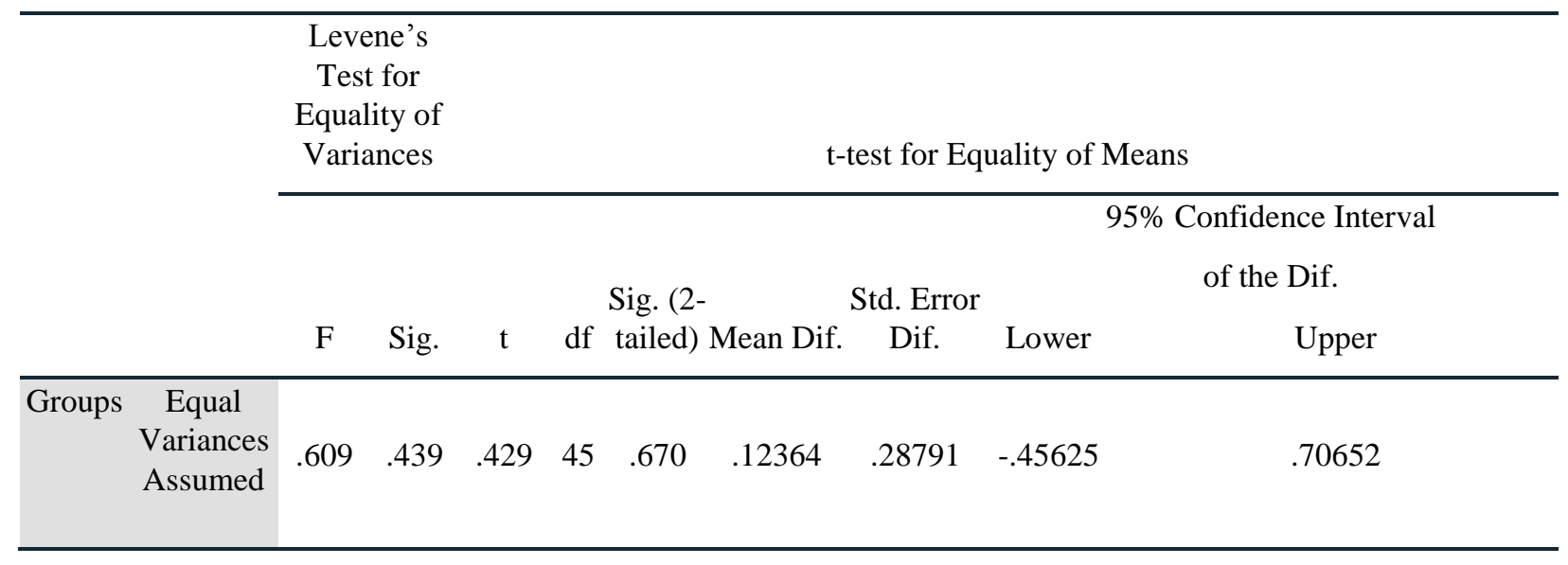

After the treatment, another independent samples t-test was conducted to examine whether there was a statistically significant difference between the means of the two groups. Table 7 shows the descriptive statistics of the DCT post- 
test. As the table shows, the means of the jigsaw group $(\mathrm{M}=16.68, \mathrm{SD}=1.04)$ and the dictogloss group $(\mathrm{M}=16.92$, $\mathrm{SD}=0.86)$ are very close. The ratio of skewness for jigsaw group and dictogloss group (0.89 and -0.56 , respectively) both falling between \pm 1.96 shows that the distribution of the scores in the groups was normal; and thus, parametric statistics for comparing two means could be run.

Table 7. Descriptive statistics of DCT post-test

\begin{tabular}{cccccccc}
\hline & $\mathrm{N}$ & Minimum & Maximum & Mean & Std. Deviation & \multicolumn{2}{c}{ Skewness } \\
\cline { 2 - 8 } & Statistic & Statistic & Statistic & Statistic & Statistic & Statistic & Std. Error \\
\hline Jigsaw & 22 & 15.00 & 19.00 & 16.6818 & 1.04135 & .438 & .491 \\
\hline Dictogloss & 25 & 15.00 & 18.00 & 16.9200 & .86217 & -.262 & .464 \\
\hline
\end{tabular}

The result of the Leven's test $(\mathrm{F}=1.83, \mathrm{p}=0.22)$, as shown in Table 8 , revealed that the assumption of homogeneity of variances was met. The result of the independent samples t-test signified that there was no statistically significant difference between the jigsaw group $(\mathrm{M}=16.68, \mathrm{SD}=1.04)$, and the dictogloss group $(\mathrm{M}=16.92, \mathrm{SD}=0.86) ; \mathrm{t}(45)=-$ $0.858, \mathrm{p}=0.396)$ after the treatment.

Table 8. Independent samples test of DCT post-test

\begin{tabular}{l}
\hline Levene's Test $\quad$ t-test for Equality of Means \\
for Equality \\
of Variances
\end{tabular}

$\begin{array}{llllll}\text { F } & \text { Sig. } & \text { t } & \text { df } & \begin{array}{l}\text { Sig. (2- Mean Dif. Std. Error 95\% Confidence Interval of } \\ \text { tailed) }\end{array} & \begin{array}{c}\text { Dif. } \\ \text { the Difference }\end{array}\end{array}$

\begin{tabular}{ccccccccccc} 
& \multicolumn{1}{c}{} & & & & Lower & Upper \\
\hline DCT & $\begin{array}{c}\text { Equal Variances } \\
\text { Assumed }\end{array}$ & 1.835 & .222 & -.858 & 45 & .396 & -.23818 & .2771 & -.79752 & .32116 \\
\hline
\end{tabular}

However, although the means of both groups showed an increase from the DCT pre-test to the DCT post-test, to ensure that the treatment had resulted in significant changes, two paired samples t-tests were conducted between the pre and post-tests of each group. Table 9 shows that there was a significant difference for both jigsaw group $t(21)=-23.729$, $\mathrm{p}<0.001$ and dictogloss group $\mathrm{t}(24)=35.715, \mathrm{p}<0.001$.

Table 9. Paired samples t-test on DCT post-test for the groups

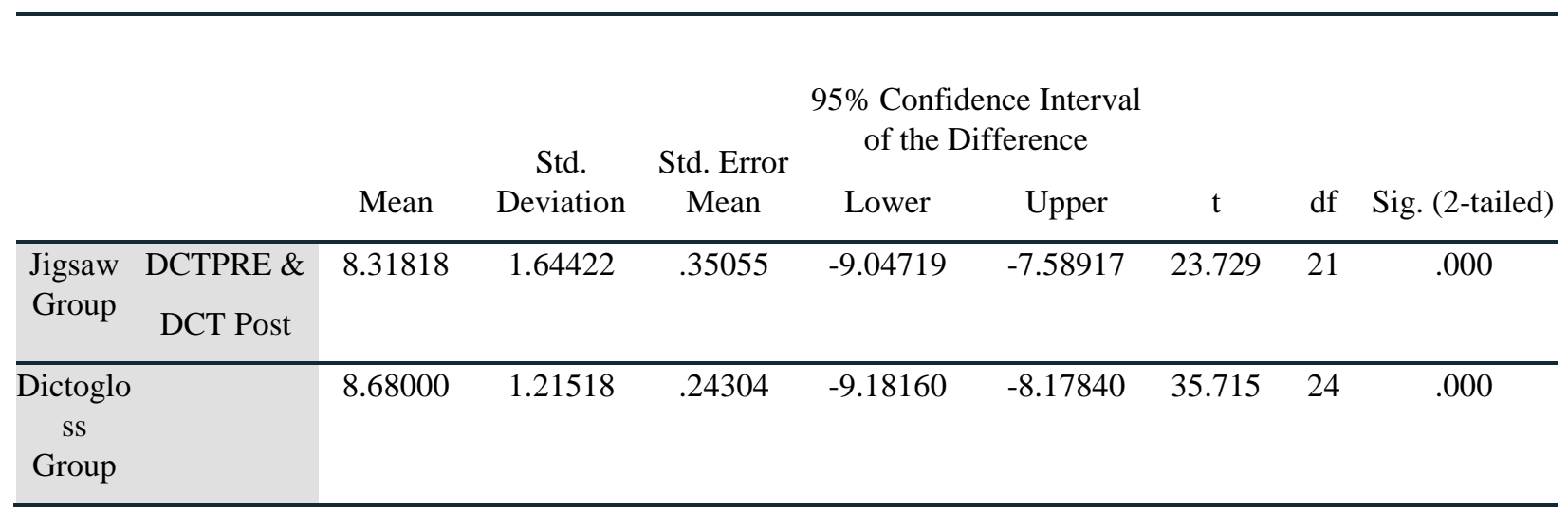




\section{Discussion}

This study sought to explore whether employing jigsaw and dictogloss tasks could improve learners' knowledge of speech acts. The comparison of the means showed no statistically significant difference between the groups after the treatment. In other words, task type did not cause a difference between the performances of groups on DCT. However, the means of the groups had improved from the pre to the post-test. Therefore, the researchers concluded that jigsaw as interactive tasks and dictogloss as focus on form tasks could have similar impacts on learners' knowledge of speech acts. Both types of tasks were successful in drawing the learners' attention to the target features while they were engaged in doing the tasks. This finding can lead the researchers to conclude that similar to facilitating linguistic components (Rashtchi \& Jalili, 2011), consciousness-raising could be useful in promoting pragmatic components of language (Abolfathiasl \& Abdullah, 2015; Zangoei, Nourmohammadi \& Derakhshan, 2014).

The present study can find support from previous studies that verify the positive role of explicit instruction on the acquisition of speech acts (Ishihara, 2004, 2007; Kondo, 2008; Takahashi, 2001; Winke \& Teng, 2010). Also, the finding is consistent with the argument by Kasper and Roever (2005) who state that mere exposure to input is not sufficient for the development of pragmatics, and output and interactional conditions, intensified by noticing and attention lead to the learning of L2 structures. Therefore, Schmidt's (1990) noticing hypothesis, which has been the subject of extensive studies in Second Language Acquisition (SLA), seems to apply to studies whose intention is promoting pragmatic knowledge of non-native speakers. However, learners' engagement with tasks for learning speech acts moves beyond mere noticing and enhances their recognition and understanding that "something is relevant to a particular aspect of language system" (Truscott \& Sharwood Smith, 2011, p.503).

The findings also verify that classroom activities, following theories of SLA, can focus both on linguistic and pragmatic competence of learners viewing them as components that follow the same rules in the process of acquisition. Conversely, the results of the current study are not in agreement with the studies that emphasize the role of natural exposure in promoting pragmatic competence (e.g., Schauer, 2006; Shively, 2011; van Compernolle \& Williams, 2013). Thus, this study can draw on the theories which suggest explicit teaching of the forms of language (Ellis, 2005; Nassaji \& Fotos, 2011).

Moreover, it can be understood that jigsaw and dictogloss tasks both can provide the appropriate requirements that, as Schmidt (2001) argues, are necessary to turn input into intake. It can also be presumed that exposure to both films and doing tasks meet the metalinguistic (reflective) function proposed by Swain's (2005) output hypothesis. Long's (1996) interactive hypothesis can also be a good source of explanation for implementing jigsaw and dictogloss tasks in the development of speech acts. The usefulness of dictogloss and jigsaw tasks in teaching speech acts as the current study showed, verifies the efficacy of such tasks in teaching other components of language (e.g., Bataineh \& Bani Younis, 2016; Marashi \& Khaksar, 2013; Mayangsari et al., 2018; Murad, 2017; Rashtchi \& Khosroabadi, 2008; Zahra, 2014).

Another reason for the finding of the study could be the use of vignettes in both classes. It seems that the films could function as a source of motivation, and could create a pleasant learning environment to affect the process of learning positively. As Gilmore (2007) believes, the use of films constructs a stimulating learning situation and offers a rich source of input for the learners. Additionally, in the present study, the films could provide an excellent source of acquaintance with the culture of the target language and helped learners' toward learning the speech acts.

The results of the present study confirm the relevance of using movies to provide a context for teaching L2 pragmatics (Abrams, 2014; Borer, 2018; Ishihara, 2014). Thus, in line with the previous research (Abrams, 2014; Birjandi \& Derakhshan, 2013; Grant \& Stark, 2001), this study suggests that native movie resources are generally useful for learners in producing specific social roles and communicative context. Media promotes learners' awareness of learning and is the most substantial variable in the process of learning the culture of the language (Moon \& Park, 2007).

Besides, the study suggests that films can be incorporated in English language classes for teaching speech acts as they can promote EFL learners' pragmatic knowledge. The use of films can be a remedy for the lack of natural exposure in EFL contexts and can raise learners' awareness of cultural differences between their L1 and the target language. The knowledge of such differences can lead to social success in different future roles that language learners might take, such as academic, business, and job market. The use of films can also be beneficial for teachers who might not teach communication skills due to their unfamiliarity with such skills (Al Aamri, 2014). This study suggests that 
employing videos, vignettes, or films can contribute to the preparation of teachers and thus help them in transferring knowledge of speech acts to EFL learners.

\section{Conclusion}

One of the primary purposes of language teaching is to enable learners to engage in fruitful communication, which is possible by learning the components of pragmatic competence, including speech acts. EFL contexts do not provide learners with exposure to the language spoken by the native speakers, nor do the textbooks used for teaching English. That is why learning interaction with speakers of English without causing misunderstandings and embarrassment is an issue for EFL learners, teachers, and practitioners. Therefore, research studies should introduce ways that can compensate for this shortcoming and lead to helping learners gain communicative competence. The current study implied that speech acts need to be addressed in the English classes via using different tasks, while the type of task does not have a decisive role in learning them. Also, the study suggested that films are authentic sources of input that play a prominent role in learning speech acts. The result of the study also showed that an active classroom environment provided by the task types could enhance the learning of adolescents. The study can have implications for teachers, practitioners, and material developers by emphasizing that materials should contain real-life scripts to provide learners with adequate input for speech acts. However, the study benefited only from a limited number of films. Having more prolonged exposure to videos and providing situations for extended communication with both male and female participants can provide educators with more reliable results.

\section{References}

Abolfathiasl, H., \& Abdullah, A. N. (2015). Pragmatic consciousness-raising activities and EFL learners' speech act performance of 'making suggestions.' Journal of Language Teaching and Research, 6(2), 333-342. http://dx.doi.org/10.17507/jltr.0602.13

Abrams, Z. I. (2014). Using film to provide a context for teaching L2 pragmatics. System 46(1), 55-64. http://doi.org/10.1016/j.system.2014.06.005

Al Aamri, R. (2014). Teaching speech acts to EFL college-level Omani learners: Requests and refusals (Unpublished master's thesis). The University of Wisconsin-River Falls, Wisconsin, USA. Retrieved September 2, 2019, from

https://minds.wisconsin.edu/bitstream/handle/1793/70953/RahmaAlAamri.pdf?sequence=1\&isAllowed=y

Ambroise, B. (2010). Speech act theory to pragmatics: The loss of the illocutionary point. Retrieved June 25, 2019, from https://halshs.archives-ouvertes.fr/halshs-00514810

Arundale, R. B. (2004). Pragmatics, conversational implicative, and conversation. In K. L. Fitch \& R. E. Sanders (Eds.). Handbook of language and social interaction (pp. 41-63). London: Routledge. https://www.routledgehandbooks.com/doi/10.4324/9781410611574.ch3

Bach, K. (2006). Speech acts and pragmatics, In M. Devitt \& R. Hanley (Eds.). The Blackwell guide to the philosophy of language (pp. 147-167). Malden, MA: Blackwell.

Bataineh, R. F., \& Bani Younis, R. A. (2016). The effect of dictogloss on Jordanian EFL teachers' instructional practices and students' writing performance. International Journal of Education and Training, 2(1), 1-11. http://www.injet.upm.edu.my/images/journal/isujun2016/The\%20Effect\%20of\%20Dictogloss\%20on\%20Jord anian\%20EFL\%20Teachers\%20Instructional $\% 20$ Practices $\% 20$ and $\% 20$ Students $\% 27 \% 20$ Writing $\% 20$ Performance.pdf

Bara, B. G. (2010). Cognitive pragmatics: The mental processes of communication. Cambridge, MA: MIT Press.

Bialystok, E. (1993). Symbolic representation and attentional control in pragmatic competence. New York, NY: Oxford University Press.

Birjandi, P., \& Derakhshan, A. (2013). Pragmatic comprehension of apology, request and refusal: An investigation on the effect of consciousness-raising video-driven prompts. Applied Research on English Language, 3(1), 67-86. http://doi.org/10.22108/are.2014.15479 
Borer, B. (2018). Teaching and learning pragmatics and speech acts: An instructional pragmatics curriculum development project for EFL learners. School of Education Student Capstone Projects, 176. Retrieved July 20, 2019, from https://digitalcommons.hamline.edu/hse cp/176

Boxer, D. (2002). Applying sociolinguistics: Domains and face-to-face interaction. Philadelphia: John Benjamins.

Ebadi, S., \& Seidi, N. (2015). Iranian EFL learners' request strategies preferences across proficiency levels and gender. Journal of Applied Linguistics and Language Research, 2(4), 65-73. http://www.jallr.com/index.php/JALLR/article/view/63/pdf_60

Ellis, R. (2003). Task-based language learning and teaching. Oxford: Oxford University Press.

Ellis, R. (2005). Principles of instructed language learning. System: An International Journal of Educational Technology and Applied Linguistics, 33(2), 209-224. https://eric.ed.gov/?id=EJ803869

Faghani, B., Derakhshan, A., \& Zangoei, A. (2015). A review on the effect of using dictogloss tasks and fake scoring on children's dictation ability. English Linguistics Research, 4(3), 58-71. http://doi.org/10.5430/elr.v4n3p58

Fleck, R. (Director). (2006). Half Nelson [Motion Picture].

Gilmore, A. (2007). Authentic materials and authenticity in foreign language learning. Language Teaching, 40(2), 97118. doi: $10.1017 / \mathrm{S} 0261444807004144$

Goldthwait, B. (Director). (2009). World's Greatest Dad [Motion Picture].

Grant, L., Starks, D. (2001). Screening appropriate teaching materials. Closings from textbooks and television soap operas. International Review of Applied Linguistics, 39(1), 39-50. http://doi.org/10.1515/iral.39.1.39

Hassall, T. (2003). Requests by Australian learners of Indonesian. Journal of Pragmatics, 35(12), 1903-1928. http://doi.org/10.1016/S0378-2166(03)00115-2

Holtgraves, T. (2007). Second language learners and speech act comprehension. Language Learning, 57(4), 595-610. http://doi.org/10.1111/j.1467-9922.2007.00429.x

Ishihara, N. (2007). Web-based curriculum for pragmatic instruction in Japanese as a foreign language: An explicit awareness-raising approach. Language Awareness, 16(1), 21-40. doi: 10.2167/la398.0

Ishihara, N. (2004). Exploring the immediate and delayed effects of formal instruction: Teaching giving and responding to compliments. Minnesota TESOL/WITESOL Journal, 21, 37-71. https://www.researchgate.net/publication/285004243 Exploring the immediate and delayed effects_of for mal_instruction_Teaching giving and responding to tompliments

Ishihara, N. (2014). Incorporating technology into pragmatics focused instruction. In N. Ishihara \& A.D. Cohen (Eds.). Teaching and learning pragmatics: Where language and culture meet (pp. 244-263). London: Routledge.

Jacobs, G., \& Small, J. (2003). Combing dictogloss and cooperative learning to promote language learning. The Reading Matrix, 3(1), 1-15. http://www.readingmatrix.com/articles/jacobs_small/article.pdf

Jafariyan Shahri, M., Matlabi, M., Esmaeili, R., \& Kianmehr, M. (2017). Effectiveness of teaching: Jigsaw technique vs. lecture for medical students' Physics course. Bali Medical Journal (Bali Med J), 6(3), 529-533. doi: $\underline{10.15562 / \mathrm{bmj} . v 6 \mathrm{i} 3.400}$

Kasper, G. (2001). Four perspectives on L2 pragmatic development. Applied Linguistics, 22(4), 502-530. http://doi.org/10.1093/applin/22.4.502

Kasper, G., \& Roever, C. (2005). Pragmatics in second language learning. In E. Hinkel (Ed.), Handbook of research in second language teaching and learning (pp. 341-358). Mahwah, NJ: Lawrence Erlbaum.

Khemlani David, M. (2016). Using movies to teach the speech act of refusals. Retrieved June 28, 2019, from https://www.researchgate.net/publication/305309139 Using_Movies to teach the Speech_Act of Refusals

Kilic, D. (2008). The effect of the jigsaw technique on learning the concepts of the principles and methods of teaching. World Applied Sciences Journal, 4(1), 109-114. https://www.researchgate.net/publication/281315386 
Konakahara, M. (2011). Requests in Japanese learners' English in comparison with British English and Japanese. https://www.researchgate.net/publication/277102103_Requests_in_Japanese_learners'_English_in_compariso $\underline{n}$ with British_English and Japanese

Kondo, S. (2008). Effects on pragmatic development through awareness-raising instruction: Refusals by Japanese EFL learners. In E. Alcon Soler \& A. Martinez-Flor (Eds.). Investigating pragmatics in foreign language learning, teaching and testing (153-177). Bristol: Multilingual Matters.

Latif, H. (2014). The place of pragmatics in the EFL classroom: Implications for teacher training. Paper presented at the 2nd International Conference on Professional Development and Reflective Teaching. Meknes: Moulay Ismail University.

Lee, C. (2018). Researching and teaching second language speech acts in the Chinese context. Singapore: Springer Nature Singapore. https://doi.org/10.1007/978-981-10-8980-0_5

Lestik, M., \& Plous, S. (2012). Jigsaw classroom. Retrieved October 24, 2012. https://en.wikipedia.org/wiki/Jigsaw_(teaching technique)

Long, M. H. (1996). The role of the linguistic environment in second language acquisition. San Diego, CA: Academic Press.

Marashi, H., \& Khaksar, M. (2013). Dictogloss or dicto-phrase: Which works better for listening comprehension? $i$ manager's Journal on English Language Teaching, 3(1), 22-29. doi: 10.26634/jelt.3.1.2147

Martinez-Flor, A., \& Fukuya, Y. J. (2005). The effects of instruction on learners' production of appropriate and accurate suggestions. System, 33(3), 463-480. http://doi.org/10.1016/j.system.2005.06.007

Meng, J. (2010). Jigsaw cooperative learning in English reading. Journal of Language Teaching and Research, 1(4), 501-504. http://doi.org/10.4304/jltr.1.4.501-504

Mengduo, Q., \& Xiaoling, J. (2010). Jigsaw strategy as a cooperative learning technique: Focusing on the language learners. Chinese Journal of Applied Linguistics, 33(4), 113-125. Retrieved March 25, 2019, from www.celea.org.cn > teic

Milleret, M. (2006). Teaching speech acts. American Portuguese Studies Association Fifth International Conference. Minneapolis, Minnesota. Retrieved May 20, 2019, from www.ncolctl.org > files > Teaching-speech-act

Moon, S., \& Park, C. (2007). Media effects on acculturation and biculturalism: A case study of Korean immigrants in Los Angeles' Korea town. Mass Communication and Society, 10(3), 319-343. http://doi.org/10.1080/15205430701407330

Murad, H. M. (2017). The effectiveness of using dictogloss strategy on developing tenth graders' English grammar learning and writing skills in Gaza. https://iugspace.iugaza.edu.ps/handle/20.500.12358/20924?locale$\underline{\text { attribute }=\text { en }}$

Nassaji, H., \& Fotos, S. (2011). Teaching grammar in second language classrooms: Integrating form-focused instruction in communicative context. New York, NY: Routledge.

Nguyen, H. (2017). Does dictogloss improve non-English major students' motivation and grammatical competence? Language Education in Asia, 8(1), 84-108. http://doi.org/10.5746/LEiA/17/V8/I1/A06/Nguyen

Nguyen, T., Pham, T. H., \& Pham, M. H. (2012). The relative effects of explicit and implicit form-focused instruction on the development of L2 pragmatic competence. Journal of Pragmatics, 44(4), 416-434. https://doi.org/10.1016/j.pragma.2012.01.003

Payne, A. (Director). (2011). The Descendants [Motion Picture].

Qin, J. (2008). The effect of processing instruction and dictogloss tasks on acquisition of the English passive voice. Language Teaching Research, 12(1), 61-82. http://doi.org/10.1177/1362168807084494

Rashtchi, M., \& Jalili, S. (2011). Consciousness-raising versus explicit grammar teaching and their impact on Iranian EFL learners' lexical inferencing https://www.sid.ir/en/journal/ViewPaper.aspx?ID=599757 
Rashtchi, M., \& Keyvanfar, A. (2007). ELT Quick 'n' Easy. Tehran: Rahnama.

Rashtchi, M., \& Khosroabadi, P. (2009). The effect of explicit focus on form and dictogloss tasks on learning English tenses. Journal of Language Studies, 1(1), 101-114.

Redford, R. (Director). (1998). The Horse Whisperer [Motion Picture].

Reece, D., \& Palmgreen, P. (2000). Coming to America: Need for acculturation and media use motives among Indian sojourners in the US. International Journal of Intercultural Relations, 24(6), 807-824. https://doi.org/10.1016/S0147-1767(00)00033-X

Rose, K. R., \& Kasper, G. (2001). Pragmatics in language teaching. Cambridge: Cambridge University Press.

Schauer, G. A. (2006). Pragmatic awareness in ESL and EFL contexts: Contrast and development. Language Learning, 56(2), 269-318. http://doi.org/10.1111/j.0023-8333.2006.00348.x

Schmidt, R. (1990). The role of consciousness in second language learning1. Applied Linguistics, 11(2), 129-158. https://doi.org/10.1093/applin/11.2.129

Schmidt, R. (2001). Attention. In P. Robinson (Ed.), Cognition and second language instruction (pp. 3-32). Cambridge: Cambridge University Press.

Searle G. R. (1976). A classification of illocutionary acts. Language in Society, 5(1), 1-23. Retrieved January 25, 2018, from http://www.jstor.org/stable/4166848

Shively, R. (2011). L2 pragmatic development in study abroad: A longitudinal study of Spanish service encounters. Journal of Pragmatics, 43(6), 1818-1835. https://doi.org/10.1016/j.pragma.2010.10.030

Sitohang, I., \& Purnawarman, P. (2015). The effectiveness of jigsaw strategy to improve students' skill in writing a recount text. English Review: Journal of English Education, 3(2), 183-189.

Swain, M. (2005). The output hypothesis: Theory and research. In E. Heinkel (Ed). Handbook of research in second language teaching and learning (pp. 471-483). Mahwah, NJ: Lawrence Erlbaum.

Swain, M., \& Lapkin, S. (2000). Task-based second language learning: The uses of the first language. Language Teaching Research, 4(3), 251-274. https://doi.org/10.1177/136216880000400304

Sykes, J. M. (2008). A dynamic approach to social interaction: Synthetic immersive environments \& Spanish pragmatics (Unpublished doctoral dissertation). The University of Minnesota. Retrieved March 23, 2019, from http://search.proquest.com/docview/304582040

Taguchi, N. (2006). Analysis of appropriateness in a speech act of request in L2 English. Pragmatics, 16(4), $513-533$. http://doi.org/10.1075/prag.16.4.05tag

Taguchi, N. (2008). Cognition, language contact, and the development of pragmatic comprehension in a study-abroad context. Language Learning, 58(1), 33-71. http://doi.org/10.1111/j.1467-9922.2007.00434.X

Takahashi, S. (2001). The role of input enhancement in developing pragmatic competence. In K. R. Rose \& G. Kasper (Eds.), Pragmatics in language teaching (pp. 171-199). Cambridge: Cambridge University Press.

Truscott, J., \& Sharwood Smith, M. (2011). Input, intake, and consciousness. The quest for a theoretical foundation. Studies in Second Language Acquisition, 33(4), 497-528. https://www.jstor.org/stable/44486032

Van Compernolle, R. A., \& William, L. (2012). Promoting sociolinguistic competence in the classroom zone of proximal development. Language Teaching Research, 16(1), 39-60. https://doi.org/10.1177/1362168811423340

Vasiljevic, Z. (2010). Dictogloss as an interactive method of teaching listening comprehension to L2 Learners. English Language Teaching, 3(1), 41-52. https://files.eric.ed.gov/fulltext/EJ1081435.pdf

Wajnryb, R. (1990). Grammar dictation. Oxford: Oxford University Press.

Winke, P., \& Teng, C. (2010). Using task-based pragmatics tutorials while studying abroad in China. Intercultural Pragmatics, 7(2), 363-399. http://doi.org/10.1515/IPRG.2010.016 
Yilmaz, Y. (2011). Task effects on focus on form in synchronous computer-mediated communication. The Modern Language Journal, 95(1), 115-132. https://doi.org/10.1111/j.1540-4781.2010.01143.x

Yi-xuan, F. (2016). Teaching speech acts in EFL classroom: An implicit pedagogy. Sino-US English Teaching, 13(7), 515-520. http://doi.org/10.17265/1539-8072/2016.07.002

Yulian, T. (2012). The effectiveness of using jigsaw and sq3r technique in instruction toward the students' reading comprehension of narrative text at the eight grade of junior high school state 8 metro academic year 2011/2012. $\begin{array}{llll}\text { Premise Journal of English 1(2), } & \text { Education, }\end{array}$ http://ojs.fkip.ummetro.ac.id/index.php/english/article/view/1119/794

Zahra, R. O. (2014). The use of jigsaw technique in improving students' ability in writing a descriptive text. Journal of English and Education, 2(1), 64-75. Retrieved March 10, 2018, from http://ejournal.upi.edu/index.php/LE/article/view/748/544

Zangoei, A., Nourmohammadi, E., \& Derakhshan, A. (2014). The effect of consciousness-raising listening prompts on the development of the speech act of apology in an Iranian EFL context. Sage Open, 4(2), 1-10. https://doi.org/10.1177/2158244014531770

Zeng, G. (2017). Collaborative dialogue in synchronous computer-mediated communication and face-to-face communication.

$\operatorname{ReCALL}$,

29(3),

257-275. https://app.dimensions.ai/details/publication/pub.1085119732?and facet_journal=jour.1271517\&and facet f or $=3468$ 


\section{Appendix A}

DCT Pretest

\section{Sample (The test has been shortened to meet word limits)}

1. You have invited your neighbors for lunch. You are cooking in the kitchen. One of the guests, who is not so close, offers to help you: "can I do anything?'. What would you say to refuse her help?

2. You are a kind teacher. In class, one of the students is text messaging. You ask your student to turn off his mobile phone. What would you say to stop him/her?

3. You are a teacher. The class is finished, and it's lunchtime. You suddenly decide to invite a student to lunch. What would you say to invite her?

4. It's the first time that you have been invited to your new next-door neighbor's house for dinner. The homemaker is preparing dinner in the kitchen. You know the homemaker. Suddenly there is a noise of pans clattering in the kitchen. You go to the kitchen to give the homemaker a hand. How do you offer to help her?

5. Your fiancé is asking you to have dinner with him, but you are not really in the mood. How would you refuse his request?

6. Your younger brother recently had a fight with your mother. You are talking to him to forget everything and reminding him that they both love each other. What's your advice?

7. You are a highly educated and polite boy who is getting married to a girl who you love so much. At times, one of the guys in your neighborhood, who is drug addicted, causes inconvenience for your fiancée. You are terribly angry and meet the guy in the street. How do you warn him not to bother your fiancée?

8. One of your old friends that used to be so close has found you at your college. You haven't seen each other for years. She wants to invite you for a coffee. But you are really busy and can't go. What would you say? 


\section{Appendix B}

\section{DCT Post-test}

\section{Sample (The test has been shortened to meet word limits)}

1. Two of your little cousins have fought over something last year. The New Year is coming, and you want to remind one of them that they have always loved each other, and they have to start their friendship again. How would you advise her?

2. It is the first time that your parents have invited your neighbors for dinner. While eating dinner, your brother starts talking about politics. You believe that it is not a good subject to talk about at the dinner table. What would you say to your brother to stop him?

3. You are in an English class as a student. You and your teacher are friendly. While the teacher is teaching, you are talking to your classmate and not listening to the teacher. The teacher looks at you angrily and calls your name to stop you from talking. What would you say to your teacher to imply that you would stop talking?

4. You are a kind nurse in a hospital. Not all patients are allowed to leave their room after midnight for walking. An old man has left his room for walking at 2 a.m. you want to stop him and warn him that it is against the hospital's laws. What would you tell him?

5. You and your naughty little sister are alone at home. You want to go out for seconds to buy some stuff. But the problem is that; whenever she is alone she goes to the bathroom and starts playing with soaps! You want to tell her that you need to go out and while you are out, she should not do such weird things. What would you tell her?

6. Your little sister's name is Drey. One of the children in your neighborhood use to bother her every day when she is coming over from kindergarten. Tell her a sentence to stop him from disturbing your sister in the street.

7. You are a teacher. In class, one of your student's cell phone rings. You politely ask the student to turn off his mobile phone.

8. It is Friday evening, and you are bored. You have prepared some food for dinner. But you prefer to have it with your friend on a picnic. You call your friend. How do you suggest going out with you to eat dinner together? 